No 4078

Studia nad Autorytaryzmem i Totalitaryzmem 43, nr 4

Wrocław 2021

https://doi.org/10.19195/2300-7249.43.4.18

\author{
RADOSŁAW ANTONÓW \\ ORCID: 0000-0003-4812-6609 \\ Uniwersytet Wrocławski \\ radoslaw.antonow@uwr.edu.pl
}

\title{
Zamówienia publiczne w II Rzeczypospolitej
}

Słowa kluczowe: zamówienia publiczne, II Rzeczpospolita, dostawy i roboty na rzecz Skarbu Państwa, przetargi, zamówienia z wolnej ręki, środki publiczne.

\section{PUBLIC PROCUREMENT IN THE SECOND POLISH REPUBLIC}

\begin{abstract}
Following Poland's regaining of independence in 1918, the country had to face a considerable range of challenges virtually at all levels of government functioning. Rebuilding the Polish state involved major expenditure, which, on the one hand, implied raising public resources in a sustainable way, while, on the other hand, the need to prioritize and use public funds efficiently while implementing public undertakings set by the state. The huge scale of the needs coupled with limited financial resources forced Poland's government, as it were, to develop suitable legal arrangements in the 1930s. Those measures were designed to spend public funds on the country's reconstruction in a manner that was efficient, purposeful, economical, and competitive. The key legal measure at that time was the Act of 15 February 1933 on Supplies and Works for the Benefit of the Treasury, Local Government and Public Law Institutions. Moreover, the relevant implementing act was Regulation of the Council of Ministers of 29 January 1937 on Supplies and Works for the Benefit of the Treasury, Local Government and Public Law Institutions. Both acts implemented innovative legal measures in terms of public-service contracts which were in force not only until the outbreak of the Second World War (they were subsequently repealed by the rules established in PRL — Polish People's Republic), considering that they also provided a basis for the new rules governing public spending implemented after 1990 and set out in the Act of 10 June 1994, Public Procurement Law.
\end{abstract}

Keywords: public procurement, the Second Polish Republic, supplies and works for the benefit of the Treasury, tenders, single-source procurement, public funding 
Polska po odzyskaniu niepodległości w 1918 roku stanęła przed szeregiem problemów występujących właściwie na wszystkich płaszczyznach funkcjonowania państwa. Dość tylko wspomnieć o trudnościach i wyzwaniach politycznych, społecznych, gospodarczych czy bezpieczeństwa. Odbudowa państwa polskiego w każdym z tych przypadków wiązała się z kosztami, co oznaczało, z jednej strony, zrównoważone gromadzenie środków, zaś z drugiej — wskazywanie priorytetów i racjonalne wydatkowanie środków publicznych na realizację założonych przedsięwzięć. Skala potrzeb państwa przy jednoczesnych ograniczonych zasobach finansowych wymusiła niejako wypracowanie odpowiednich rozwiązań prawnych umożliwiających sprawne, oszczędne i konkurencyjne wydatkowanie $\mathrm{z}$ trudem zgromadzonych środków publicznych właściwie na odbudowę państwa polskiego, a nie — jak to ma miejsce w Polsce w XXI wieku — w przeważającej mierze na realizację wybranych przedsięwzięć publicznych. Za takim stanowiskiem autora wydaje się przemawiać bardzo trudna sytuacja Polski i Polaków po odzyskaniu niepodległości i - z uwagi na ograniczone środki publiczne - konieczność dokonywania wyborów w zakresie planowania priorytetowych inwestycji i przedsięwzięć gospodarczych i społecznych.

Jednolite i obowiązujące dla całego obszaru państwa polskiego procedury dotyczące wydatkowania środków publicznych w II Rzeczypospolitej weszły w życie dopiero po pokonaniu trudności związanych z obowiązywaniem w Polsce po odzyskaniu niepodległości różnych systemów prawnych będących spuścizną po państwach zaborczych ${ }^{1}$. Pomimo trudności z tym związanych już w 1918 roku zamówienia rządowe poddane zostały prawu zawartemu w dekrecie o utworzeniu Urzędu Rozdzielczego ${ }^{2}$, a rok później przy Ministerstwie Spraw Wojskowych powołany został Główny Urząd Zaopatrywania Armii ${ }^{3}$, co było kluczowym zadaniem z uwagi na odbudowę sprawnej armii, a tym samym - bezpieczeństwa Polski. W 1933 roku weszły w życie, obowiązujące dla całego obszaru państwa polskiego, przepisy regulujące wydatkowanie środków pochodzących z budżetu państwa ${ }^{4}$. Pierwszym aktem prawnym w tym obszarze była Ustawa z dnia 15 lutego 1933 roku o dostawach i robotach na rzecz Skarbu Państwa, samorządu oraz instytucyj prawa publicznego ${ }^{5}$. Rozwiązania prawne zawarte w tej ustawie, choć były lakoniczne, ogólne i pozbawione szczegółowych rozwiązań prawnych, posiadały jednak istotny walor w postaci jednolitości tego prawa dla całego obszaru odrodzonego państwa

1 Zob. R. Antonów, Ewolucja zamówień publicznych w Polsce, [w:] Zamówienia publiczne, red. P. Bielarczyk, W. Gonet, A. Wójtowicz-Dawid, Warszawa 2021, s. 25 n.

2 Dekret w przedmiocie utworzenia Urzędu Rozdzielczego w celu centralizacji zamówień rządowych (Dz. Praw P. Pol. z 1918 r. Nr 19, poz. 55).

3 Ustawa z dnia 11 kwietnia 1919 roku o utworzeniu Głównego Urzędu Zaopatrywania Armji (Dz. Praw P. Pol. z 1919 r. Nr 32, poz. 265).

${ }^{4}$ Zob. T. Kocowski, Rozwój prawa zamówień publicznych, „Wrocławsko-Lwowskie Zeszyty Prawnicze" 11, 2020, s. 154.

5 Ustawa z dnia 15 lutego 1933 roku o dostawach i robotach na rzecz Skarbu Państwa, samorządu oraz instytucyj prawa publicznego (Dz.U.R.P. z 1933 r. Nr 19, poz. 127). 
polskiego. Akt ten wydany został na mocy art. 44 Ustawy z dnia 17 marca 1921 roku Konstytucja Rzeczypospolitej Polskiej ${ }^{6}$. Ustawa ta, licząca zaledwie pięć artykułów, nie zawierała w swojej treści rozwiązań proceduralnych, jak to ma miejsce w przypadku współczesnych polskich ustaw dotyczących przedmiotowego zagadnienia, uchwalonych po roku 1990. Ustawa z 1933 roku wskazywała, a właściwie regulowała prawnie, trzy główne zasady w tym obszarze.

Pierwsza odnosiła się do prawa stanowienia aktów wykonawczych i zasad w zakresie procedur i mechanizmów udzielania zamówień publicznych. Zgodnie z przyjętymi w przedmiotowej ustawie rozwiązaniami Rada Ministrów na podstawie art. 1 ustalała $\mathrm{w}$ drodze rozporządzeń sposoby i warunki udzielania zamówień na dostawy i roboty oraz przyjmowania dokonanych dostaw i robót dla Skarbu Państwa, samorządu terytorialnego, instytucji prawa publicznego, zakładów i przedsiębiorstw państwowych, tudzież dla zakładów i funduszów przez państwo zarządzanych, $\mathrm{z}$ wyłączeniem monopoli państwowych i tych przedsiębiorstw przemysłowych, handlowych i górniczych, które zostały wydzielone z ogólnej administracji państwowej i uznane za przedsiębiorstwa posiadające samoistną osobowość prawną, w drodze rozporządzeń Rady Ministrów wydanych na podstawie rozporządzenia Prezydenta Rzeczypospolitej z dnia 17 marca 1927 roku o wydzielaniu $\mathrm{z}$ administracji państwowej przedsiębiorstw państwowych przemysłowych, handlowych i górniczych oraz o ich komercjalizacji ${ }^{7}$. Ponadto Rada Ministrów zobowiązana była do wydania $\mathrm{w}$ drodze rozporządzeń specjalnych przepisów normujących warunki dostaw i robót w monopolach i przedsiębiorstwach państwowych posiadających samoistną osobowość prawną. Wreszcie w granicach upoważnień ustalonych Rozporządzeniami Rady Ministrów poszczególni ministrowie w porozumieniu z ministrami przemysłu i handlu oraz skarbu mieli prawo wydawać szczegółowe przepisy o dostawach i robotach dla podległych im działów administracji państwowej oraz instytucji będących pod ich nadzorem. Dla administracji ogólnej i samorządu terytorialnego ministrem właściwym do wydawania takich przepisów był minister spraw wewnętrznych działający w porozumieniu z ministrami przemysłu i handlu oraz skarbu, tudzież z innymi zainteresowanymi ministrami ${ }^{8}$. Istotną więc cechą regulacji w zakresie zamówień publicznych w badanym okresie były akty prawne $\mathrm{w}$ randze rozporządzenia.

Druga zasada, fundamentalna $\mathrm{z}$ uwagi na wyzwania stojące przed odrodzonym państwem polskim, dotyczyła przyjęcia preferencji krajowych. Z punktu widzenia interesu Polski, w kontekście odbudowy gospodarczej i społecznej, było to kluczowe rozwiązanie. Polegało to na udzielaniu zamówień w pierwszej

${ }^{6}$ Zob. Ustawa z dnia 17 marca 1921 roku Konstytucja Rzeczypospolitej Polskiej (Dz.U.R.P. z 1921 r. Nr 44, poz. 267).

7 Zob. Rozporządzenie Prezydenta Rzeczypospolitej z dnia 17 marca 1927 roku o wydzielaniu z administracji państwowej przedsiębiorstw państwowych, przemysłowych, handlowych i górniczych oraz o ich komercjalizacji (Dz.U. z 1927 r. Nr 25, poz. 195).

8 Por. art. 1 (Dz.U.R.P. z 1933 r. Nr 19, poz. 127). 
kolejności wszystkim przedsiębiorstwom krajowym, a więc polskim. Co ważne, zasada ta obejmowała zarówno krajowych wykonawców robót, jak i dostawców wyrobów i surowców. W myśl bowiem przepisów art. 2 ustawy z 1933 roku dostawy i roboty powinny być z reguły wykonywane przez przedsiębiorstwa krajowe mające siedziby w kraju oraz przy wykorzystaniu surowców oraz wszelkich wyrobów pochodzenia krajowego w takim stopniu, aby produkcja ich została całkowicie wykorzystana. Zgodnie z treścią przywołanego artykułu właściwi ministrowie $\mathrm{w}$ porozumieniu $\mathrm{z}$ ministrami przemysłu $\mathrm{i}$ handlu oraz rolnictwa $\mathrm{i}$ reform rolnych byli zobowiązani do ustalania w drodze rozporządzeń obowiązku wykonywania zamówień tylko z surowców i wszelkich wyrobów krajowego pochodzenia, względnie wysokości obowiązującej domieszki surowców krajowych. Celem takich rozwiązań było, w pierwszej kolejności, wykorzystanie wszelkich dostępnych zasobów krajowych, a tym samym umożliwienie rozwoju krajowej przedsiębiorczości. Z zakładów zagranicznych dopuszczone natomiast były te, które posiadały w odpowiedniej wysokości wydzielony kapitał w kraju i dysponowały prawem działalności oraz były tam zarejestrowane. Takie rozwiązania prawne, z jednej strony, regulowały zasady wydatkowania środków publicznych, z drugiej zaś - przyczyniały się do odbudowy gospodarczej Polski. Obowiązek wykorzystywania rodzimych surowców i produktów przez polskie przedsiębiorstwa dawał rękojmię ożywienia gospodarczego kraju9

Trzecią zasadą było wprowadzenie mechanizmów wygaszania dotychczasowych rozwiązań administracyjnych i prawnych w obszarze wydatkowania środków publicznych. W tym kontekście ustawodawca na podstawie przepisów art. 3 ustawy wprowadził zasady i terminy utraty mocy obowiązującej wszelkich dotychczasowych przepisów prawnych o dostawach i robotach dla Skarbu Państwa, samorządu terytorialnego, instytucji prawa publicznego, zakładów i przedsiębiorstw państwowych niewydzielonych z ogólnej administracji państwowej na podstawie rozporządzenia prezydenta Rzeczypospolitej z dnia 17 marca 1927 roku o wydzielaniu z administracji państwowej przedsiębiorstw państwowych przemysłowych, handlowych i górniczych oraz o ich komercjalizacji, tudzież dla zakładów i funduszów przez państwo zarządzanych ${ }^{10}$. W myśl przepisów art. 3 ustawy wszelkie dotychczasowe przepisy regulujące obszar zamówień publicznych traciły moc obowiązującą w terminie ustalonym w rozporządzeniu Rady Ministrów wydanym na podstawie art. 1 omawianej ustawy ${ }^{11}$. Wykonanie ustawy z 1933 roku powierzone zostało, w myśl przepisów art. 4 ustawy, ministrowi przemysłu i handlu oraz innym, każdemu we własnym zakresie działania ${ }^{12}$. Ustawa weszła w życie 24 marca $1933 \mathrm{roku}^{13}$.

\footnotetext{
9 Por. art. 2 (Dz.U.R.P. z 1933 r. Nr 19, poz. 127).

10 Por. art. 3 (Dz.U.R.P. z 1933 r. Nr 19, poz. 127).

11 Por. art. 3 (Dz.U.R.P. z 1933 r. Nr 19, poz. 127).

12 Por. art. 4 (Dz.U.R.P. z 1933 r. Nr 19, poz. 127).

13 Por. art. 5 (Dz.U.R.P. z 1933 r. Nr 19, poz. 127).
} 
Przepisy wykonawcze do ustawy o dostawach i robotach na rzecz Skarbu Państwa, samorządu oraz instytucyj prawa publicznego zostały wprowadzone w życie dopiero w 1937 roku Rozporządzeniem Rady Ministrów z dnia 29 stycznia 1937 roku o dostawach i robotach na rzecz Skarbu Państwa, samorządu oraz instytucyj prawa publicznego ${ }^{14}$. To obszerne rozporządzenie składające się z 50 paragrafów uregulowało zasadniczo kwestie odnoszące się do warunków uczestnictwa wykonawców $\mathrm{w}$ procesie zamówień publicznych, zagadnień formalnych związanych z udzielaniem zamówień publicznych, trybów udzielania zamówień (pisemny przetarg ofertowy nieograniczony i ograniczony; publiczny przetarg ustny, zamówienie z wolnej ręki, zakup bezpośredni za zwykłym rachunkiem), procesu realizacji zamówień (umowy, przyjmowanie wykonanych dostaw i robót oraz regulowanie rachunków). Istotną kwestię w przedmiotowym rozporządzeniu stanowiło powtórzenie kluczowych przepisów ustawy z 1933 roku. W myśl bowiem § 2 rozporządzenia zamówienia na dostawy lub roboty powinny być z reguły udzielane przedsiębiorstwom mającym siedziby w kraju lub zagranicznym posiadającym odpowiedniej wysokości wydzielony kapitał, dopuszczonym do działalności i zarejestrowanym w kraju. Ponadto warunki techniczne dostaw i robót powinny być tak ustalone, aby mogły zostać wykonane przy użyciu sił krajowych i surowców oraz wszelkich wyrobów pochodzenia krajowego, albo jeżeli ich produkcja w kraju była niewystarczająca - z użyciem tych surowców i wyrobów w takim stopniu, aby produkcja ich została całkowicie wykorzystana ${ }^{15}$.

Zgodnie z $\S 1$ rozporządzenia przepisy miały zastosowanie do dostaw i robót na rzecz Skarbu Państwa, samorządu terytorialnego, instytucji prawa publicznego, między innymi instytucji ubezpieczeń społecznych i przez nie powołanych, zakładów i przedsiębiorstw państwowych, w szczególności takich jak Polska Poczta, Telegraf i Telefon oraz Polskie Koleje Państwowe, tudzież na rzecz zakładów i funduszów przez państwo zarządzanych, z wyłączeniem monopoli państwowych i tych przedsiębiorstw przemysłowych, handlowych oraz górniczych, które zostały wydzielone z ogólnej administracji państwowej i uznane za przedsiębiorstwa posiadające samoistną osobowość prawną w drodze rozporządzeń Rady Ministrów wydanych na podstawie Rozporządzenia prezydenta Rzeczypospolitej z dnia 17 marca 1927 roku o wydzielaniu z administracji państwowej przedsiębiorstw państwowych przemysłowych, handlowych i górniczych oraz o ich komercjalizacji. Przepisom rozporządzenia nie podlegały natomiast Lasy Państwowe ${ }^{16}$.

Ważnym zagadnieniem w przedmiotowym rozporządzeniu było swego rodzaju planowanie w zakresie dostaw lub robót polegające na udzielaniu ich — jak przyjęto -

14 Rozporządzenie Rady Ministrów z dnia 29 stycznia 1937 roku o dostawach i robotach na rzecz Skarbu Państwa, samorządu oraz instytucyj prawa publicznego (Dz.U.R.P. z 1937 r. Nr 13, poz. 92).

15 Zob. A. Panasiuk, System zamówień publicznych w Polsce, Warszawa 2004, s. 10 n.

16 Por. $§ 1$ (Dz.U.R.P. z 1937 r. Nr 13, poz. 92). 
o ile możności, w takim czasie, by ich wykonanie przypadało na tzw. sezony martwe. Zamówienia na dostawę artykułów rolnych należy, o ile możności, udzielać tak, aby ich wykonanie przypadało przede wszystkim na sezony wzmożonej podaży, zwłaszcza w okresach bezpośrednio następujących po żniwach i wykopach. Wykonywanie dostawy lub roboty w sezonie martwym nie powinno w żadnym razie powodować powiększenia kosztów dostawy lub roboty jak również obniżenia ich jakości ${ }^{17}$.

Z uwagi na konieczność niwelowania dysproporcji w rozwoju pomiędzy poszczególnymi rejonami kraju, będących spuścizną po zaborach, ustawodawca zadbał również o równomierny rozwój gospodarczy. W myśl § 14 rozporządzenia z 1937 roku zamówienia na dostawy i roboty znacznych rozmiarów, niezależnie od formy ich dokonywania, powinny być udzielane w ten sposób, aby możliwie równomiernie uwzględniać potrzeby wszystkich okręgów gospodarczych państwa ${ }^{18}$. Pomocne $\mathrm{w}$ tym miały być szczegółowe przepisy wydawane na podstawie $\S 15$ rozporządzenia. W jego granicach właściwi ministrowie mogli wydawać w porozumieniu z ministrami przemysłu i handlu oraz skarbu szczegółowe przepisy o dostawach i robotach dla podległych im działów administracji państwowej oraz instytucji będących pod ich nadzorem. Dla administracji ogólnej i samorządu terytorialnego przepisy takie wydawać mógł minister spraw wewnętrznych w porozumieniu z ministrami przemysłu i handlu oraz skarbu lub z innymi zainteresowanymi. Minister przemysłu i handlu w zakresie produkcji przemysłowej, a minister rolnictwa i reform rolnych, w porozumieniu $\mathrm{z}$ ministrem przemysłu i handlu w zakresie produkcji rolnej, wydawali ogólne wytyczne na każdy rok gospodarczy co do udzielania zamówień na dostawy i roboty, które miały szczególne znaczenie ze względu na interesy gospodarcze danej gałęzi gospodarstwa narodowego. Wytyczne w przypadku dostaw i robót dla potrzeb wojska wydawane były również w porozumieniu z ministrem spraw wojskowych. W zakresie produkcji przemysłowej (w tym na potrzeby wojska) i rolnej ustalane były również warunki udzielania zamówień za granicą lub przedsiębiorstwom zagranicznym zarejestrowanym w kraju, oraz określane sezony martwe poszczególnych grup przemysłu ${ }^{19}$.

$\mathrm{Z}$ uwagi na potrzebę równomiernego rozwoju społecznego i gospodarczego ustawodawca przyjął zasadę pierwszeństwa: po pierwsze, dla rynku miejsca przeznaczenia dostawy lub wykonania roboty, a po drugie, w pierwszej kolejności dla drobnych wytwórców i ich organizacji. W myśl przepisów § 13 rozporządzenia, jeżeli oferowana cena i pozostałe warunki były jednakowe, należało przy udzielaniu zamówienia na dostawę lub robotę przyznać pierwszeństwo rynkowi miejsca przeznaczenia dostawy lub wykonania roboty, przy czym przy dostawach i robotach wchodzących w zakres rzemiosła należało przyznać pierwszeństwo rzemieślniczym organizacjom o charakterze zarobkowym, następnie — rzemieślnikom, wreszcie - przemysłowcom. Ustawodawca wyraźnie więc nakazał

17 Por. § 14 (1) (Dz.U.R.P. z 1937 r. Nr 13, poz. 92).

18 Por. 14 (2) (Dz.U.R.P. z 1937 r. Nr 13, poz. 92).

19 Por. $§ 15$ (Dz.U.R.P. z 1937 r. Nr 13, poz. 92). 
preferowanie organizacji rzemieślniczych, a tym samym rzemieślników, przed przemysłem. Ponadto przy udzielaniu zamówień na dostawę artykułów rolnych, w przypadku oferowania jednakowych cen i warunków przez kupców i rolników bądź zrzeszenia rolników, należało przyznać pierwszeństwo rolnikom, następnie zaś - zrzeszeniom rolniczym ${ }^{20}$. W tym wypadku pierwszeństwo przed zrzeszeniami rolników miał rolnik.

Proces wydatkowania środków publicznych podlegał również kontroli pod względem prawidłowości i jakości wykonania zamówienia. Po pierwsze, zgodnie z przepisami $\S 24$ rozporządzenia na przetargu mogli być obecni delegaci Kontroli Państwowej ${ }^{21}$, po drugie, realizacja zadania podlegała każdorazowo odbiorowi protokolarnemu zawierającemu w swojej treści decyzję o przyjęciu albo odrzuceniu bezwarunkowym lub warunkowym wykonanej dostawy lub roboty, bądź wniosek o przyjęcie lub odrzucenie, jeżeli decyzja w tej mierze pozostawała w kompetencjach instancji wyższej ${ }^{22}$.

Przepisy ustawy z 1933 roku i rozporządzenia z 1937 roku, choć nowatorskie jak na okres dwudziestolecia międzywojennego, przestały obowiązywać wraz z przemianami ustrojowymi w Polsce, które nastąpiły po zakończeniu drugiej wojny światowej. Wprowadzenie w Polskiej Rzeczypospolitej Ludowej (PRL) zasad socjalistycznej gospodarki, centralnego planowania gospodarczego i likwidacji sektora prywatnego pozostawało w sprzeczności z omawianymi przepisami dotyczącymi udzielania zamówień publicznych w II RP. Do rozwiązań tych powrócono dopiero w 1992 roku, po rozpoczęciu prac nad projektem Ustawy z dnia 10 czerwca 1994 roku o zamówieniach publicznych ${ }^{23}$. Polskie przepisy obowiązujące $\mathrm{w}$ dwudziestoleciu międzywojennym stanowiły istotną podwalinę prawa zamówień publicznych w Rzeczypospolitej Polskiej ${ }^{24}$.

\section{Bibliografia}

Antonów R., Ewolucja zamówień publicznych w Polsce, [w:] Zamówienia publiczne, red. P. Bielarczyk, W. Gonet, A. Wójtowicz-Dawid, Warszawa 2021.

Dekret w przedmiocie utworzenia Urzędu Rozdzielczego w celu centralizacji zamówień rządowych (Dz.Praw P.Pol. z 1918 r. Nr 19, poz. 55).

Finanse publiczne i prawo finansowe, red. C. Kosikowski, E. Ruśkowski, Warszawa 2003.

Kocowski T., Rozwój prawa zamówień publicznych, „Wrocławsko-Lwowskie Zeszyty Prawnicze” 11, 2020.

Panasiuk A., System zamówień publicznych w Polsce, Warszawa 2004.

20 Por. $§ 13$ (Dz.U.R.P. z 1937 r. Nr 13, poz. 92).

21 Por. $\$ 24$ (Dz.U.R.P. z 1937 r. Nr 13, poz. 92).

22 Por. $§ 42$ (Dz.U.R.P. z 1937 r. Nr 13, poz. 92).

23 Zob. R. Antonów, op. cit., s. 34 n.

24 Zob. Finanse publiczne i prawo finansowe, red. C. Kosikowski, E. Ruśkowski, Warszawa 2003, s. 686 n. 
Rozporządzenie Prezydenta Rzeczypospolitej z dnia 17 marca 1927 roku o wydzielaniu z administracji państwowej przedsiębiorstw państwowych, przemysłowych, handlowych i górniczych oraz o ich komercjalizacji (Dz.U. z 1927 r. Nr 25, poz. 195).

Rozporządzenie Rady Ministrów z dnia 29 stycznia 1937 roku o dostawach i robotach na rzecz Skarbu Państwa, samorządu oraz instytucyj prawa publicznego (Dz.U.R.P. z 1937 r. Nr 13, poz. 92).

Ustawa z dnia 11 kwietnia 1919 roku o utworzeniu Głównego Urzędu Zaopatrywania Armji (Dz.Praw P.Pol. z 1919 r. Nr 32, poz. 265).

Ustawa z dnia 17 marca 1921 roku Konstytucja Rzeczypospolitej Polskiej (Dz.U.R.P. z 1921 r. Nr 44, poz. 267).

Ustawa z dnia 15 lutego 1933 roku o dostawach i robotach na rzecz Skarbu Państwa, samorządu oraz instytucyj prawa publicznego (Dz.U.R.P. z 1933 r. Nr 19, poz. 127). 